\title{
Bio-Sweetener (Stevia Rebaudiana Bertoni): Boon for Rural India
}

\author{
Shashi Kant Shukla*, Rajesh Kumar and Anupam Dikshit* \\ Centre of Rural Technology and Development, University of Allahabad, India
}

Submission: September 10, 2017; Published: September 14, 2017

"Corresponding author: Shashi Kant Shukla \& Anupam Dikshit, Centre of Rural Technology and Development, University of Allahabad, India; Email: anupambplau@rediffmail.com; shashibplau@gmail.com

\begin{abstract}
Sugar and its products are the most important additional part of our diet (taste) especially in rural areas. The increase, sugar amount in body causes several diseases such as diabetes. To, the taste addicted person, it is very difficult to replace tasty products particularly sweets but some medicinal plant parts are used as alternate of sugar; Stevia rebaudiana (Bertoni) is one of them. It is an herbaceous perennial plant which belongs to family Asteraceae, contains stevioside, natural sweetener. This plant is cultivated in some parts of India and is a rich source of crude protein i.e $16 \%$ in leaves and $6 \%$ in stem with low fat content. This plant can be a very good source of health and income.
\end{abstract}

Keywords: Rural; Stevia; Stevioside; Diabetes; Medicinal Plants

\section{Introduction}

Sugar is one of the most important components of daily life which is obtained from two major sources. One source is sugarcane which is cultivated in tropical or sub-tropical regions of the world and another one is sugar beet, in temperate regions. In the production of sugar, dominancy of sugarcane is noteworthy. India is the second most country of globe in the production and consumption of sugar which is approximately 16 percent of world. Apart from these aspects sugar is also known for causing diseases, especially diabetes. Moreover Nancy Appleton has reported 141 diseases caused by sugar due to suppression of immune system [1], increase in reactive oxygen species (ROS) [2] and reduction of stability of body against bacterial infection [3]. Excess consumption of sugar can also lead to several conditions such as ovarian cancer [4], causes copper deficiency [5], hypoglycaemia [6] and heart diseases [7] etc. The aforesaid risk of sugar can be reduced by using some natural alternatives. Stevia rebaudiana is one of the alternatives to that of sugar. Stevia rebaudiana Bertoni is a well-known medicinal plant and has unique properties.

\section{Cultivation}

It is mostly used in diabetes and belongs to family Asteraceae. The plant is native of South America specially Paraguay and Brazil [8]. Stevia can be grown easily in semi-humid subtropical condition, red and sandy loam soil with pH 6.5 to 7.5. In India, Stevia is cultivated in some parts of Rajasthan, Maharashtra,
Kerala and Orissa [9]. The seeds of this plant remain viable for a restricted time and having a very low germination rate with heterozygous species.

\section{Classification/Taxonomical Position}

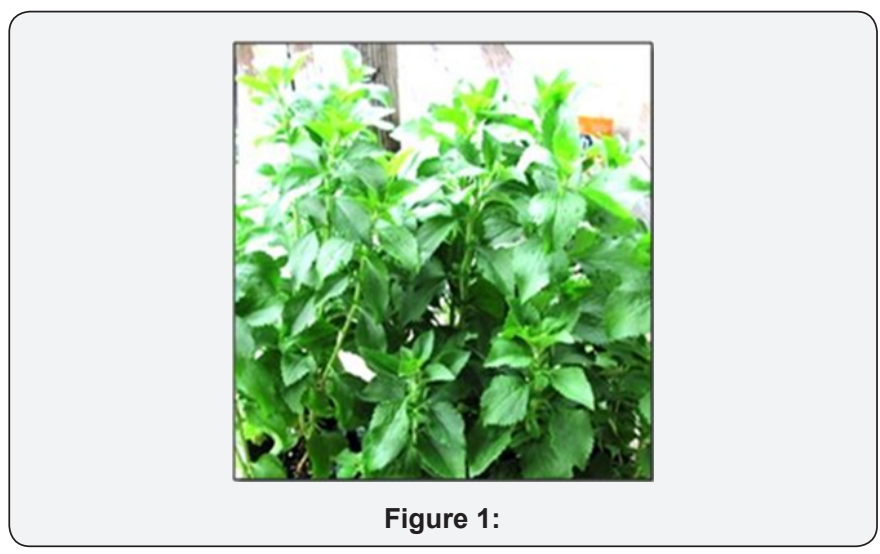

Kingdom: Plantae

Class: Dicotyledons

Sub class: Polypetalae

Series: Thalamiflorae

Order: Asterales 


\section{Organic and Medicinal Chemistry International Journal}

Family: Asteraceae

Genus: Stevia

Species: Rebaudiana (Figure 1).

\section{Uses of Stevia rebaudiana Bertoni}

Stevia leaves are big source of stevioside and rebaudioside [10] in which stevioside; a chief source is 300 times sweeter than sucrose at $0.4 \%$ solution [11]. The Stevia leaves can be used as a potential source for substitution for sugar in the form of stevioside and extract of Stevia leaves. South American people have been using leaves of Stevia in place of sugar [12]. So, for the human welfare and clinical microbiology, there is a need to have enhanced production of Stevia plants. The required yield can be achieved by huge production of Stevia to meet the current demand. S. rebaudiana cultivation in large scale can be produced by the use of some eco-friendly bio inoculants.

\section{Conclusion}

A majority of people are facing the problem of diabetes which has been a big issue in present scenario, ultimately drawing the attention towards its management. Available traditional remedies are either costly or having severe side effects. Few medicinal plants provide better cure as they are inexpensive, less-toxic, reliable and efficient when compared to others and $S$. rebaudiana is one of them which exhibited very good antioxidant activity too.

\section{References}

1. Sanchez A, JL Reeser, HS Lau, PY Yahiku, RE Willard, et al. (1973) Role of Sugars in Human Neutrophilic Phagocytosis. Am J Clin Nutr 261: 1180-1184.

2. Mohanty, Hamouda W, Garg R, Aljada A, Ghanim H, et al. (2000) Glucose Challenge Stimulates Reactive Oxygen Species (ROS) Generation by Leucocytes. J Clin Endocrin Metab 85(8): 2970-2973.

3. Ringsdorf W, Cheraskin E, Ramsay R (1976) Sucrose, Neutrophilic Phagocytosis and Resistance to Disease. Dental Survey 52(12): 46-48.

4. Takahashi ET (1982) University School of Medicine. Wholistic Health Digest. 41.

5. Fields M, Ferretti RJ, Smith JC Jr, Reiser S (1983) Effect of Copper Deficiency on Metabolism and Mortality in Rats Fed Sucrose or Starch Diets. J Nutr 113(7): 1335-1345.

6. Dufty W (1975) Sugar Blues. New York: Warner Books.

7. Yudkin J (1971) Sugar Consumption and Myocardial Infarction. Lancet. 6: 1(7693):296-297.

8. Sivaram L, Mukundan U. (2003) In vitro culture studies on Stevia rebaudiana. In Vitro Cell Dev Biol Plant 39: 520-523.

9. Goyal SK, Samsher, Goyal RK (2010) Stevia (Stevia rebaudiana) a biosweetener: a review. Int J Food Sci Nutr 61(1): 1-10.

10. Ahmed MB, Salahin M (2007) An efficient method for in vitro clonal propagation of a newly introduced sweetener plant Stevia rebaudiana in Bangladesh. Am J Sci Res 2: 121-125.

11. Geuns JMC (2003) Molecules of interest stevioside. Phytochemistry 64: 913-921.

12. Chatsudthipong V, Muanprasat C (2009) Stevioside and related compounds: therapeutic benefits beyond sweetness. Pharmacol Ther 121(1): 41-54.

\section{Your next submission with Juniper Publishers will reach you the below assets}

- Quality Editorial service

- Swift Peer Review

- Reprints availability

- E-prints Service

- Manuscript Podcast for convenient understanding

- Global attainment for your research

- Manuscript accessibility in different formats

( Pdf, E-pub, Full Text, Audio)

- Unceasing customer service

Track the below URL for one-step submission https://juniperpublishers.com/online-submission.php 